\title{
新澤正秀 学位論文審査要旨
}

$\begin{array}{cccc}\text { 主査 } & \text { 西村 元 延 } \\ \text { 副主查 } & \text { 山 } & \text { 一 } & \text { 博 } \\ \text { 同 } & \text { 稲 垣 喜 三 }\end{array}$

\section{主論文}

Changes of motor evoked potentials during descending thoracic and thoracoabdominal aortic surgery with deep hypothermic circulatory arrest

(超低体温循環停止を用いた胸部下行および胸腹部大動脈手術における運動誘発電位の変 化)

(著者 : 新澤正秀、吉谷健司、湊谷謙司、入江友哉、荻野均、大西佳彦) 平成24年 Journal of Anesthesia 26巻 160頁～167頁

\section{参考論文}

1. Jugular bulb desaturation during off-pump coronary artery bypass surgery （オフポンプ冠動脈バイパス術における内頝静脈球部の酸素飽和度低下）

(著者：三浦倫一、吉谷健司、川口昌彦、新澤正秀、入江友哉、内田整、大西佳彦、 Mackensen G. Burkhard)

平成21年 Journal of Anesthesia 23巻 477頁～482頁

2. The efficacy of motor-evoked potentials on cerebral aneurysm surgery and new-onset postoperative motor deficits

（脳動脈瘤手術における運動誘発電位の有効性と新たに発症した術後運動障害）

(著者 : 入江友哉、吉谷健司、大西佳彦、新澤正秀、三浦倫一、日下裕介、宮崎信一郎、 宮本享)

平成22年 Journal of Neurosurgical Anesthesiology 22巻 247頁～251頁

3. Clinical comparison of an echocardiograph-derived versus pulse counter-derived cardiac output measurement in abdominal aortic aneurysm surgery

(腹部大動脈瘤手術における心エコーによる心拍出量測定と動脈圧波形解析法による 心拍出量測定の臨床的比較)

(著者：日下裕介、吉谷健司、入江友哉、稲冨佑弦、新澤正秀、大西佳彦) 平成24年 Journal of Cardiothoracic and Vascular Anesthesia 26巻 223頁〜226頁 


\section{学 位 論 文 要 旨}

Changes of motor evoked potentials during descending thoracic and thoracoabdominal aortic surgery with deep hypothermic circulatory arrest

（超低体温循環停止を用いた胸部下行および胸腹部大動脈手術における運動誘発電位の変 化)

脊髄虚血による対麻痺は胸部下行大動脈瘤や胸腹部大動脈瘤の人工血管置換術における 重篤な合併症の一つである。運動誘発電位（MEP） は運動神経路の機能的統合性のモニター として、術中の春髄前角細胞機能のモニタリングに期待されている。MEPは麻酔薬、筋弛緩 薬や体温などに影響を受けるとの報告があるが、ヒトにおけるMEPに対する体温変動の影響 に関してのデータはほとんど報告されていない。本研究では超低体温循環停止法を用いた 胸部下行・胸腹部大動脈瘤手術において、体温変動によるMEPの変化を調查した。

\section{方 法}

超低体温循環停止法を用いた胸部下行・胸腹部大動脈瘤手術を予定した連続15症例を対 象とした。MEPの測定は全身麻酔下に経頭蓋電気刺激により誘発し、上肢は短拇指外転筋、

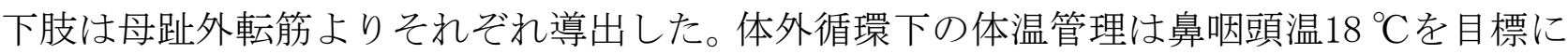
全身冷却した後に循環停止とし、循環再開後は $37{ }^{\circ} \mathrm{C}$ 目標に復温した。MEPは鼻咽頭温を 基準に $1{ }^{\circ} \mathrm{C}$ 変化毎に記録し、同時にMEP導出部位の手掌および足底部の温度も記録した。

\section{結 果}

全身冷却時、MEPの振幅は上肢・下肢ともにほぼ直線的に減少し、潜時は直線的に延長し

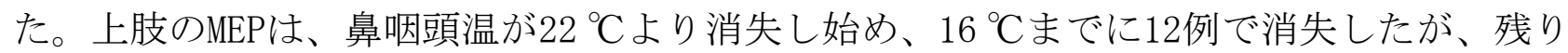
の3例は循環停止まで導出可能であった。下肢のMEPは鼻咽頭温 $24{ }^{\circ} \mathrm{C}$ り消失し始め、 $16{ }^{\circ} \mathrm{C}$ までに10例で消失したが、残りの5例は循環停止まで導出可能であった。

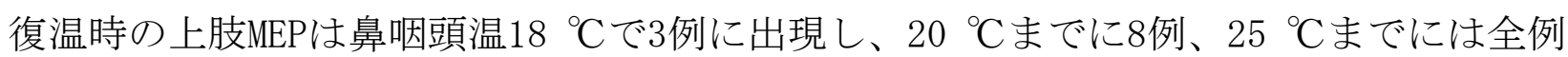
で導出された。上肢MEPの振幅は復温とともに増大し、鼻咽頭温 $25{ }^{\circ} \mathrm{C}$ でコントロール值の

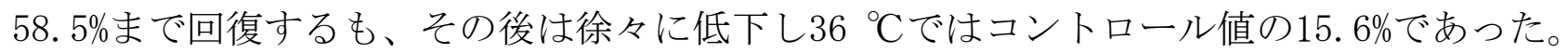

一方、下肢では上肢と比較してMEP回復時の鼻咽頭温のばらつきが大きく、 $19{ }^{\circ} \mathrm{C} て ゙ 2$ 例に 出現し、 $20{ }^{\circ} \mathrm{C} ら 30{ }^{\circ} \mathrm{C}$ 間に6例、 $31{ }^{\circ} \mathrm{C}$ か $37{ }^{\circ} \mathrm{C}$ でに残りの7例が確認された。また、 
潜時は上・下肢とも復温に伴い短縮し、復温終了時にはほぼコントロール值に回復した。

\section{考 察}

Browningらはネコを用いて直腸温 $28{ }^{\circ} \mathrm{C}$ な゙全身冷却し、MEPの振幅が増加したと報告し ている。Meylartsらはブタを用いて脳脊髄液の泠却灌流により脊髄冷却したところ、脳脊 髄液が29. $6{ }^{\circ} \mathrm{C} の$ 際にMEPの振幅が最大となり、その後冷却の進行とともに振幅は低下した

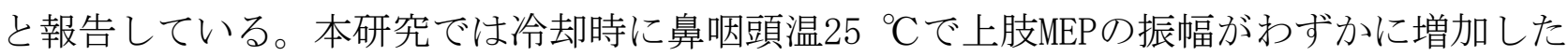
が有意ではなかった。動物実験との差異の原因は不明だが、急速な全身冷却が影響してい るかもしれない。

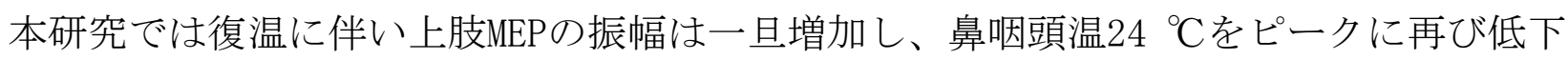

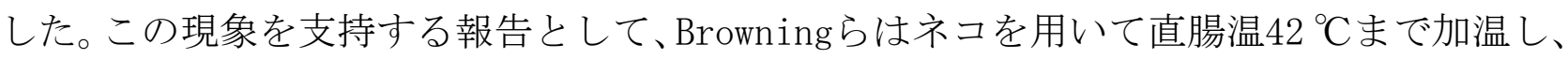
MEPの振幅が減少したとの報告がある。また、Oroらもラットを加温し、直腸温 $42{ }^{\circ} \mathrm{C}$ 以上で MEPの振幅が抑制されたと報告している。脊髄虚血の診断基準として、しばしばMEPの振幅 がコントロール值の $25 \%$ 未満に減少することが用いられるが、本研究で見られたような復温 時のMEPの振幅減少は、誤った臨床判断に導く可能性がある。

復温時の下肢 $\mathrm{NEP}$ は上肢に比較して、出現までに多くの時間を要した。その原因の一つと して中枢温とMEP測定部未梢温の温度較差が考えられた。復温時に手掌温は鼻咽頭温とほぼ 平衡に上昇したのに対し、足底温は鼻咽頭温より遅れて上昇し、復温が完了しても約 $30^{\circ} \mathrm{C}$ に留まっていた。筋肉温の低下は、twitch反応を減少させると報告されている。

その他、本研究ではいくつかの限界を認めた。サンプル数が少なく、体温変動の影響以 外にも開放吻合などの術式の違いや、体外循環自体の影響や体外循環によるプロポホール などの血中濃度への影響など、多くの要因がMEPに影響を与えていると推察された。

\section{結 論}

全身冷却時には、MEPの振幅は鼻咽頭温の低下とともに直線的に減少し、 $16{ }^{\circ} \mathrm{C}$ ぞに 15 例中 10 例でMEPは消失したが、残りの5例では循環停止までMEPが導出された。復温時は、上 肢MEPは鼻咽頭温 $25^{\circ} \mathrm{C}$ までに全例で出現したのに対し、下肢MEPの出現時は体温のばらつき が大きく、長い時間を要した。また、復温時の上肢MEPの変化は、体温上昇がMEPの振幅を 減少させる可能性を示唆した。本研究では手術終了時に多くの症例でMEPの回復が十分でな いにもかかわらず術後に運動麻疩を認めなかった。超低体温循環停止法を用いた胸部下行 および胸腹部大動脈瘤手術において、MEPの春髄虚血のモニターとしての有用性は懐疑的で あった。MEPの振幅には体温変動以外にも多くの要因が影響していると推測された。 